\title{
On the Splitting of the Ego in the Process of Reality-Interpreting, Ego- Trauma, Defence, and Fantasy
}

\author{
David Gordon Bain
}

Philosophy-Psychology and Post-Freudian Neo-Psychoanalysis, Newmarket, Ontario, Canada

Corresponding author: David Gordon Bain, Philosophy-Psychology and Post-Freudian Neo-Psychoanalysis, Newmarket, Ontario, Canada, E-mail: dgbainsky@yahoo.com

Received: Jan 21, 2016; Accepted: Jan 28, 2016; Published: Jan 30, 2016

Copyright: (๑) 2016 Bain DG. This is an open-access article distributed under the terms of the Creative Commons Attribution License, which permits unrestricted use, distribution, and reproduction in any medium, provided the original author and source are credited.

\section{Short Communication}

My name is David Gordon Bain. I am putting this essaylecture out here as a trial balloon. If it goes over well, then there could be many to follow. I have studied psychology for more than 40 years now, and the work-as-a-whole that I have in mind under the title given above, would constitute the main essence of what I have learned in these 40 years, in as comprehensive and integrative a fashion as I can present it. First, let me give you a quick resume of my education and experience in psychology.

I entered The University of Waterloo, Ontario in 1974, and in my last year there, in 1979, I wrote my Honours Thesis in psychology for one of the earliest cognitive-behaviour theorists and therapists $\mathrm{Dr}$ Donald Meichenbaum. Today, looking back at that essay from a psychoanalytic or neopsychoanalytic perspective, I would say that it was an essay on 'Central Ego Functioning and Dysfunctioning' from a largely Cognitive-General Semantic, and Humanistic-Existential perspective.

However, by the time I finished that essay, I realized that there was a much 'deeper' body of knowledge that I needed to study and investigate specifically, or at least mainly, the 'cognitive templates' that exist in our subconscious mind that have been there since we were children.

Alfred Adler used to call this aspect of our cognitive functioning our 'private logic' because it entailed much of what is both 'unique' and 'common' in terms of the early generalizations we tend to make about life and people including our own self-image and the way we approach and/or avoid people. Much of what we might call 'cognitive dysfunctioning' is 'housed' within these early cognitive templates and because they are put together and 'cemented' or 'conditioned' into place they generally include areas of 'over-generalization', 'extreme logic', and 'unbearable ideas' that will not only affect the way that each individual child will view the world and him or herself for the rest of his or her life, but also in 'dysfunctional' ways in terms of extreme perspectives, emotions, and behaviour that may bring that person to a therapist many, many years later. In addition to calling this brand of 'logic' a person's 'private logic', Adler also referred to it as his or her 'lifestyle' or 'lifestyle plan' I took courses in Adlerian Psychology in 1980 and 1981 at The Adlerian Institute in Ontario and had the pleasure of hearing Dr Harold Mosak and Dr Stan Shapiro speak on different subject matters before I left the Institute. What I learned there in those two years would remain with me and have influence my present work. I use the term 'TLT' Transference-Lifestyle Templates' to describe my unique integrative presentation of Adlerian and Freudian Psychoanalysis and Neo-Psychoanalysis. I also was active at The Gestalt Institute in Toronto between 1979 and 1991, which in turn left its mark on my evolving 'multi-integrative presentation'.

There are two further influences of the 1980s and 1990s that I would like to briefly mention here. Before we start to delve deeper into the subject matter of my presentation. Firstly, while reading a book on Gestalt Therapy one day, I happened upon the name of 'Hegel' and started to realize how Hegel's 'dualistic and dialectically integrative logic usually presented as: 1 . thesis; 2 . anti or counter-thesis; and 3. dialectic integration or synthesis played a major role in the thinking of Freud, Jung, and Perls among others in their respective 'intra-psychic conflict models' of the personality as well as their respective approaches to psychotherapy. This reintroduction to Hegel I had also been briefly introduced to his brand of thinking while I was at The University of Waterloo opened up the whole subject matter of Western and Eastern Philosophy of which I followed down that investigative trail at my own leisure and pace for quite a few years until the second of these last two influences started to take over.

I was browsing through a downtown Toronto bookstore one day when I happened upon a writer who sounded rebellious and interesting but who I had never heard of before: Dr. Jeffrey Masson. In walking out of that bookstore, I had purchased Masson's 'Assault On Truth: Freud's Suppression of The Seduction Theory'; and also, 'Final Analysis: The Making and Unmaking of a Psychoanalyst'. Somewhere along the line around this same time, I had also purchased Janet Malcolm's 'In The Freud Archives'... and before I knew it, I had been 'seduced' into the whole 'Seduction Theory Controversy' which would lead me into the early history of Psychoanalysis, and into a more general passion for Psychoanalysis of every major brand: Pre-Psychoanalysis, Classical Psychoanalysis, Object Relations, and Self Psychology mainly a passion that I still hold to this day. In university, I had also read quite a few Erich 
Fromm books: Escape From Freedom, Man For Himself, The Art of Loving, and The Sane Society which also gave me more of a humanistic-existential perspective on Psychoanalysis or 'Neo'-Psychoanalysis all of which were coming together in my many evolving models of the human psyche, each one changing with the addition of each new and significant influence, Eric Berne and Transactional Analysis being another important one.

All of which brings us to the matter at hand: 1. a new, enlarged, multi-integrative model of the human psyche; and 2. 'the splitting of the human psyche or the ego in the process of function and defence.

In 1938, in Freud's second last significant paper, Freud wrote a rather remarkable essay called: 'Splitting of The Ego in The Process of Defence'. It was remarkable in at least two different ways: 1 . it linked Freud's latest work to his earliest work his earliest 'pre-psychoanalytic' work involving his 'trauma theory' (1893-1895) which after 1896, he largely rejected and/or ignored until this last shocking little essay of 1938 where Freud, basically on the verge of death's doorstep, still showed some remarkable new insight into the workings of the human mind, perhaps partly influenced by the beginning of Melanie Klein's early work in the 1930s, which would open up the new and exciting branch of present day psychoanalysis called 'Object Relations'. Thus, this little paper not only linked Freud's last work with his earliest work, but it also helped to open up the door to 'the splitting of the ego' which would become one of the defining points of Object Relations and later Transactional Analysis. It also can be viewed as the starting point of this present work I am offering up to you.

I would like to say one more thing before I leave you in 'Essay-Lecture 1' here. Beginning somewhere in the mid-1990s, I started emailing Dr Masson sporadically at first, sometimes over a year apart.

However, at some point my similar perspective on The Seduction Theory Controversy to the one that he laid out in 'Assault' even though I took a more integrative approach to the controversy in which I told him that I wanted to 'bridge' the gap between Pre-Classical and Classical Psychoanalysis, and between Trauma Theory and Fantasy Theory seemed to resonate with him loud enough, along with my sincerity and passion for the subject matter, that he granted me an online interview with him in 2010. I think both of us were happy with the results of the short interview which was a summary of his thinking and feeling about 30 years after the beginning of the huge controversy and scandal he caused in The Psychoanalytic Establishment just before Anna Freud died in 1982. Before the controversy, Masson had been a close friend with one of the esteemed elder members of the Psychoanalytic Establishment at that time Dr. Kurt Eissler who convinced Anna Freud into the 'unabridged, uncensored Freud to Fliess letters, and more...as the newly hired 'Projects Director of The Freud Archives'. 